THE SUPREME COURT OF PENNSYLVANIA 



\section{THE SUPREME COURT}

\section{OF PENNSYLVANIA}

Life and Law in the Commonwealth,

1684-2017

Edited by John J. Hare

THE PENNSYLVANIA STATE UNIVERSITY PRESS 
Names: Hare, John J., editor.

Title: The Supreme Court of Pennsylvania: life and law in the Commonwealth, 1684-2017 / edited by John J. Hare.

Description: University Park, Pennsylvania : The Pennsylvania State University Press, [2018] | Includes bibliographical references and index.

Identifiers: LCCN 2017033576 | ISBN 9780271080116 (cloth : alk. paper)

Summary: "A narrative history of the Supreme Court of Pennsylvania. Explores the court's notable decisions and why they matter in the broader context of Pennsylvania and American law and history"-Provided by publisher.

Subjects: LCSH: Pennsylvania. Supreme Court—History. | Law—Pennsylvania— History.

Classification: LCC KFP 512 .P46 2018 | DDC 347.748/035—dc23

LC record available at https://lccn.loc.gov/2017033576

Copyright (C) 2018 The Pennsylvania State University All rights reserved

Printed in the United States of America

Published by The Pennsylvania State University Press,

University Park, PA 16802-1003

The Pennsylvania State University Press is a member of the Association of American University Presses.

It is the policy of The Pennsylvania State University Press to use acid-free paper. Publications on uncoated stock satisfy the minimum requirements of American National Standard for Information Sciences-Permanence of Paper for Printed Library Material, ANSI Z39.48-1992. 